\title{
UNIVERSITYOF
}

FORWARD

THINKING

WESTMINSTER用

WestminsterResearch

http://www.westminster.ac.uk/westminsterresearch

\section{The Effect of the L'Aquila Earthquake on Labour Market}

Outcomes

Di Pietro, G. and Mora, T

This is a copy of the accepted author manuscript of the following article: Di Pietro, G. and Mora, T 2015. The Effect of the L'Aquila Earthquake on Labour Market Outcomes. Environment and Planning C: Government and Policy, 33 (2), 239-255, 2015.

The final definitive version is available from the publisher, Sage at:

https://dx.doi.org/10.1068/c12121r

(c) The Author(s) 2015

The WestminsterResearch online digital archive at the University of Westminster aims to make the research output of the University available to a wider audience. Copyright and Moral Rights remain with the authors and/or copyright owners.

Whilst further distribution of specific materials from within this archive is forbidden, you may freely distribute the URL of WestminsterResearch: ((http://westminsterresearch.wmin.ac.uk/)).

In case of abuse or copyright appearing without permission e-mail repository@westminster.ac.uk 


\title{
The effect of the L'Aquila earthquake on labour market outcomes
}

\begin{abstract}
This paper analyses the effects of the L'Aquila earthquake on labour market outcomes for a period of 15 months after its occurrence. Our estimates are based on a difference-indifferences strategy that compares residents of L'Aquila with residents of a control area before and after the earthquake. Three main results emerge from our empirical analysis: 1) the earthquake led to a modest, but significant, reduction in the probability of participating in the labour force for a period of 9 months after the event, 2) while the employment likelihood decreased in the quarter immediately after the earthquake, it increased in the next 4 quarters, and 3) there is evidence of significant heterogeneous effects by gender and level of education.
\end{abstract}

Keywords: L'Aquila earthquake; labour force participation; employment; difference-indifferences

Word count: 7,001 (including tables and figures but excluding bibliography and footnotes)

The authors would like to thank three anonymous referees and the Editor for their valuable comments and suggestions. However, responsibility for errors remains with us. 


\section{Introduction}

On April $6^{\text {th }} 2009$ central Italy was struck by a severe earthquake measuring up to 8-9 on the MCS (Mercalli-Cancani-Sieberg) scale. Its epicentre was near L'Aquila, the capital of the Abruzzi region, which is situated about 70 miles northeast of Rome. The earthquake killed 309 people, which makes it the deadliest earthquake to hit Italy since the 1980 Irpinia earthquake. In addition to this, as reported by Masi (2009), it injured about 1,600 people and rendered more than 65,000 people homeless. Thousands of buildings and infrastructure were seriously damaged or destroyed. The historical centre of the city of L'Aquila, which hosts numerous public offices, a university campus and several medieval buildings and churches, was especially hit hard. More than 2,000 firms were forced to close their business while others remained operational in business but suffered major damages because of the loss of stocks, tools and machinery. The economic damage caused by the L'Aquila earthquake is estimated to be approximately 540 million euro (Commissariato delegato per la ricostruzione in Abruzzo, 2011).

Not only did the press, media and the international community show great interest in L'Aquila in the days immediately following the earthquake, but further attention was paid to the situation in L'Aquila in July 2009 during the G8 summit. Indeed, following the natural disaster, the Italian government decided to move the location of the $35^{\text {th }} \mathrm{G} 8$ summit from the Sardinian city of La Maddalena to L'Aquila.

This paper uses Labour Force Survey (LFS) individual-level data recently released by the Italian Institute of Statistics (ISTAT), in which information is for the first time available at provincial level: information was previously available only at regional level. The paper examines the effects of the L'Aquila earthquake on labour market outcomes for a period of 15 months after the event. Policymakers who are assessing economic recovery in L'Aquila and those who are concerned about how to deal with future disasters need to be aware how 
the earthquake impacted various aspects of the local economy, including the local labour force and local employment levels. Our estimates are based on a difference-in-differences (DiD) strategy which compares residents of L'Aquila with residents of a control area before and after the earthquake.

Our work adds to previous research on the economic impact of natural disasters in two main aspects. First, although there are many studies on this topic, to the best of our knowledge, this is the first one focusing on a European country. This is not surprising as Europe is significantly less exposed to natural catastrophes than other areas of the world. For instance, Jones (1981) argues that in Asia the probability of dying in a seismic disaster is about 30 times higher than in Europe. More recently, Cavallo and Noy (2009) report that between 1970 and 2008 approximately $99 \%$ of individuals affected by natural disasters lived in the Asia-Pacific region, Latin America, the Caribbean or Africa. Second, unlike much of the prior literature that has used area-level data to analyse the economic consequences of natural disasters, this is one of the few studies relying on individual-level data. This allows us to examine the effect of the earthquake on labour market outcomes controlling for a number of demographic characteristics. Another advantage of employing individual-level data is that it enables us to examine whether the earthquake had a differential impact across important subgroups of the population.

One concern with this type of analysis is sample selection. Since natural disasters typically lead to short- and long-distance migration of the affected population, there is the risk that the sample drawn from the hit area in the aftermath period may not include evacuees. However, ISTAT, which is responsible for the administration of the Italian LFS, has ensured that the samples collected from L'Aquila in the months immediately after the earthquake are comparable with those collected in the months preceding the natural disaster (see ISTAT press release, March $24^{\text {th }} 2010$ ). ISTAT employees were able to contact a large majority of 
those individuals who were displaced from their homes as a result of the earthquake. This is also supported by the observation that, as shown in the Appendix, the average characteristics of residents of L'Aquila before and after the earthquake are found to be similar in the dataset.

Our empirical analysis delivers three main results. First, the L'Aquila earthquake reduced the probability of participating in the labour force for a period of 9 months after the event. Second, while the earthquake had no overall significant impact on the employment likelihood, significant opposing effects occurred over time. While the employment likelihood decreased in the quarter immediately after the earthquake, it increased in the next 4 quarters. Third, there are significant heterogeneous effects by level of education and gender. While the L'Aquila earthquake has worsened the labour market situation for more educated individuals, the opposite occurred for the less educated. Additionally, in the short-term the employment effects of this natural disaster are mostly confined to men.

The remainder of the paper is organized as follows. Section 2 summarises the results of previous empirical work on the economic consequences of natural disasters. Section 3 illustrates pre-earthquake economic conditions in L'Aquila. While Section 4 describes the data and depicts the empirical strategy, estimates are presented and discussed in Section 5. Section 6 concludes.

\section{The economics of natural disasters}

Despite much research on natural disasters, there is still substantial debate about their economic effects. Some studies argue that these events may have short-term negative consequences followed by eventual recovery. For example, Belasen and Polachek (2008) find that hurricanes in Florida cause a drop in employment, but this effect dissipates over time. Their finding is, however, called into questioned by other works claiming that natural disasters, especially large scale ones, tend to have a persistent detrimental effect on economic 
activity. Coffman and Noy (2012) show that the economy of the Hawaiian island of Kauai has yet to recover, 18 years after being hit by Hurricane Inki. Cavallo et al. (2010) estimate that large disasters may lead to some $30 \%$ drop in output per capita in the affected country 10 years after their occurrence. This long-term adverse effect can be triggered by several factors. Companies and individuals may not be willing to invest in the affected area if they perceive that this may be hit again by similar environmental shocks. Additionally, natural disasters may determine a significant exodus of individuals from the affected area with negative consequences on the local economy. Noy (2012) shows that in July 2011, 6 years after Hurricane Katrina, the population of New Orleans was $21 \%$ lower than the week before this disaster. Finally, the permanent decline in the level of output may also be caused by the negative effect of natural disasters on human capital accumulation. Xu (2011) finds that cohorts born after the earthquake that hit Tangshan in 1976 exhibit lower school completion rates than those born before this event.

On the other hand, several studies conclude that natural disasters can actually bring economic benefits to the affected areas. Ewing et al. (2005) conclude that Corpus Christi's labour market improved following Hurricane Bret in August 1999. Ewing and Kruse (2002) show that hurricane recovery activities may lead to a long-run economic improvement of the area. In a seminal paper that uses data from many countries for the 1990-2004 period, Skidmore and Toya (2002) conclude that the frequency of climatic disasters is positively correlated with total factor productivity (TFP) growth and GDP per capita. One explanation for this is that such shocks give firms the opportunity to update capital stock and use new technology (Cuaresma et al., 2008). More generally, it is possible to argue that increased investment in the rebuilding process may provide an important stimulus to the economy.

In an attempt to explain these mixed results, it has been suggested that different types of disasters can have contrasting effects on economic activity. Loayza et al (2009) argue that, 
while disasters affecting the provision of essential intermediate inputs in production (such as long droughts that destroy agricultural production) may have an adverse effect on economic growth, other environmental shocks mainly causing losses of capital stock (such as earthquakes) may boost the economy. Similarly, Kim (2010) finds that natural disasters may have a differential impact on human capital. While geological disasters may depress human capital investments, climatic disasters may contribute to human capital accumulation.

It should also be borne in mind that several factors may mitigate the negative effects of natural disasters. The level of economic development gives an implicit insurance against these events. This explains why low-income countries are likely to suffer more severe consequences relative to high-income countries. Increases in income allow individuals to take additional precautionary measures to reduce exposure to environmental shocks. Furthermore, low-income countries tend to be relatively specialised in agriculture, which is the sector most affected by natural disasters (Albala-Bertrand, 1993). Low-income countries may also have problems in financing reconstruction, given that their insurance and re-insurance markets are significantly shallower (Noy, 2012) and they are less able to adopt counter-cyclical fiscal policies (Ilzetzki and Végh, 2008).

The institutional framework is another crucial determinant of a nation's vulnerability to natural disasters. Using data from large scale disasters between 1984 and 2004, Raschky (2008) finds that institutional factors such as government stability and investment climate reduce the adverse effects of environmental shocks. Institutions may play an important role in helping nations to cope with natural disasters in both pre and post shock periods. They implement ex-ante disaster management policies (e.g. zoning laws and building codes, early warning systems, construction of preventive measures such as dykes and levees) and ensure that these are enforced. One of the advantages of those regions/areas that are well-prepared to cope with natural disasters is that their residents are less likely to be displaced by these events 
(Martin, 2012), and hence they are less likely to experience unfavourable labour market outcomes (Karoly and Zissimopoulos, 2010). Furthermore, a good institutional framework also ensures that resources are efficiently allocated in the process of reconstruction. In a recent work, Cheong (2011) emphasizes the importance of central government involvement in the distribution of disaster compensation following the Hebei Spirit oil spill in Korea in December 2007. Given the larger organizational and financial resources of the central government relative to local governments, the former is more prepared to deal with the compensation procedure and file claims than the latter ones.

Finally, a well-developed financial sector may insulate nations from environmental shocks. It ensures that projects in risky locations are not financed and that, in general, more stringent safety standards are applied. Toya and Skidmore (2007) finds empirical support for this argument as they conclude that financial development is inversely correlated to economic damage caused by natural disasters.

\section{The economy of L'Aquila before the earthquake}

The earthquake has the potential to have aggravated the economic problems of L'Aquila, which had already been experiencing a decline in output growth since 2000. According to ISTAT figures, while the province of L'Aquila showed an average annual real value added growth rate of $0.4 \%$ between 1996 and 2000, this figure dropped to $0.1 \%$ between 2001 and 2007. In the latter period, not only was the economic performance of L'Aquila worse than the national average (Italian average annual real value added growth rate was $1.1 \%$ ), but it was also lower relative to that exhibited by the other provinces of the Abruzzi region. This meant that, while in 1995 L'Aquila was the richest province of Abruzzi in terms of per capita GDP, by 2007 it had become the poorest one. The economic decline of L'Aquila can largely be attributed to the process of deindustrialisation and to the closure of several large firms, 
especially in the telecommunication and electronic sectors (Mauro, 2009). This slowdown in the economy led to a deterioration in the labour market, with the unemployment rate reaching $7.7 \%$ in 2007 (the corresponding figure for Italy as a whole was $6.1 \%$ ).

The reduction in manufacturing output levels has however been at least partially replaced by growth in the service sector. Two issues are worth mentioning in this context. First, many individuals who lost their job because of deindustrialisation have opened small businesses in the city centre attempting to satisfy the needs of a large pool of customers represented by the students of the University of L'Aquila (Abruzzo24ore.tv, 2012). Before the earthquake, approximately 27,000 students were enrolled at this University and a significant proportion of them were not originally from L'Aquila, therefore needing a larger number of services including accommodation. To emphasise the relative importance of students within the economy of L'Aquila, it has been estimated that the annual turnover generated by them was 90 million euro, which represented about $6 \%$ of the income produced by the city of L'Aquila in 2008 (Cavallaro, 2011). Second, the tourism sector experienced an upswing in the years before the earthquake. In 2008, hotels, restaurants and similar establishments accounted for 7.3\% of total firms in L'Aquila (Ajassa, 2009). This figure is higher than the corresponding Italian national average and is even higher than that in some other Italian cities known for their art and culture. This expansion was made possible through the significant promotion of skiing facilities available in the Abruzzi (for instance, Campo Imperatore) and by encouraging tourists to visit medieval buildings and churches located in L'Aquila's historical centre. 


\section{Data and Methodology}

To examine the effects of the L'Aquila earthquake on labour market outcomes, we use data from 6 waves of the LFS, a quarterly survey of about 77,000 Italian households conducted by the ISTAT. Whilst the first of these waves (i.e. first quarter of 2009) covers the period before the L'Aquila earthquake, the other 5 waves (i.e. second, third and fourth quarters of 2009 and first and second quarters of 2010) refer to the period after this earthquake. Unfortunately, there are no other waves of this survey containing information at provincial level and referring to the pre-earthquake period.

To estimate the effects of the L'Aquila earthquake on labour market outcomes, a DiD approach is employed. There are two main reasons for choosing this technique over others (e.g. propensity score matching (PSM) or a combination of PSM and DiD). First, our choice is determined by data availability considerations. For instance, the small size of our dataset in the pre-earthquake period ${ }^{1}$ does not make it particularly well suited for PSM methods. Second, in contrast to PSM that controls only for observable covariates, the DiD in effect accounts for the impact of both observable and unobservable characteristics.

Two indicators for labour market outcomes are used: the probability of participating in the labour force and the likelihood of being in employment. Following the ISTAT definition, our attention is focused on individuals aged between 15 and 64 .

\footnotetext{
${ }^{1}$ Given the small number of observations for residents of L'Aquila in the pre-earthquake period it would be difficult to find matches and one cannot really afford to lose any of these observations. In fact, as argued by Bryson et al. (2002), a fundamental requirement for the applicability of matching lies in the availability of variables observed before the intervention occurs.
} 
While $Y_{\text {Aquila }}^{\text {After }}$ denotes the probability of labour force participation (1, otherwise 0 ) or employment likelihood (1, otherwise 0) for an individual in L'Aquila after the earthquake, $Y_{\text {Aquila }}^{\text {Before }}$ denotes the same probability of labour force participation or employment likelihood in L'Aquila before the earthquake. The difference $\left(Y_{\text {Aquila }}^{\text {After }}-Y_{\text {Aquila }}^{\text {Before }}\right)$ is then an estimator of the effect of the earthquake. However, this estimator is confounded to the extent that it also picks up the effect of other factors, influencing our indicators of labour market outcomes, which were changing at the same time as the earthquake. In an attempt to correct for this, we contrast this difference with the difference between the probability of participating in the labour force, or employment likelihood, before and after the earthquake in an appropriate control area that was plausibly uninfluenced by this natural disaster. The choice of this comparison area is crucial as it should capture counterfactual trends in the probability of labour force participation, or employment likelihood, in the absence of the earthquake. Although the choice of the counterfactual is, by definition, not testable as it involves unobserved scenarios, we argue that the province of Perugia constitutes a suitable control area in light of the following six considerations:

1) Both Perugia and L'Aquila are capitals of regions. While Perugia is the capital of Umbria, L'Aquila is the capital of Abruzzi. This means that they both host regional governments' offices in addition to provincial and municipal ones. This suggests that, although data on the proportion of workers in the public sector are not available, one would expect this figure to be similar in the two provinces.

2) Both Perugia and L'Aquila have a university campus attracting a considerable number of students. This means that in both provinces a significant proportion of the population is made up of university students. Our dataset shows that, in the first quarter of 2009, the proportion 
of university students among people aged between 15 and 64 in L'Aquila was 6.9\%, while the corresponding figure for Perugia was $4.9 \%$.

3) The provinces of Perugia and L'Aquila are geographically close, but not adjacent, as shown in Figure 1. Marchand (2012) suggests that it is good practice to avoid control areas directly bordering the target area, as it is important to create a buffer between the treatment and comparison groups to reduce spillover effects. This consideration is reinforced by the findings of a recent study by McComb et al. (2011). These authors argue that in the aftermath of natural disasters, output in adjacent unaffected regions may actually increase as it provides substitute production capacity and shelter.

\section{Insert Figure 1 about here}

4) The industry structure was similar across the control and target areas before the earthquake. According to ISTAT, in 2008 in L'Aquila the proportion of workers employed in the agriculture and fishing sectors was $4.9 \%$, while the corresponding figure in Perugia was $3.9 \%$. The proportions of people working in manufacturing and services were also quite close across these provinces. In 2008 in L'Aquila the proportions of workers employed in manufacturing and services were $29.6 \%$ and $65.5 \%$ respectively, whereas the corresponding figures in Perugia were $33.1 \%$ and 63\%. As observed by Korkeamäki and Uusitalo (2009), it is especially important that the control and target areas display a similar industrial composition as this suggests that they are likely to follow the same business cycle.

5) Time trends were similar in the two areas. A necessary condition for our DiD strategy to be valid is that in the pre-earthquake period the control and target areas exhibited similar time trends in our indicators of labour market outcomes. If these time trends were similar in the pre-earthquake period, then it is likely that they would have been similar in the postearthquake period if L'Aquila had not been hit by the earthquake. Unfortunately, our dataset 
cannot be used to test the validity of this assumption since, as mentioned above, only one wave of the LFS before the earthquake is available. Because of these data availability issues, the only way to test this assumption is to employ ISTAT annual provincial aggregate data on labour force participation and employment rate between 2004 and 2008 (these data can be downloaded from http://www.istat.it ). Data before 2003 are not comparable with later years because of a change in the methodology used by the ISTAT to calculate labour market indicators. Additionally, quarterly data for this period are unavailable. Figure 2 shows that between 2004 and 2008 the movements of labour force participation and employment rate in L'Aquila followed quite closely those observed in Perugia. This similarity is reassuring as it suggests the DiD assumption of parallel trends in the absence of treatment is met. At this point, it is worth emphasizing that the $\mathrm{DiD}$ approach does not require that the level of the outcome variable is similar across the target and control areas. All that is required is that the time trend is similar in the pre-treatment period (Dorsett, 2005).

\section{Insert Figure 2 about here}

Although Figure 2 provides visual evidence that in the pre-earthquake period time trends in labour force participation and employment rate in the target and control areas were similar, this can be formally tested by employing an approach followed by Görlitz (2010). Using annual data for the 2004-2008 period, the difference in each of our two labour market indicators between L'Aquila and Perugia is first computed, and then this is regressed against a constant and a linear time trend. Because the coefficient on the linear time trend in both regressions is not statistically significant at the usual confidence levels, we cannot reject the hypothesis that the target and control areas had the same time trends in labour force participation and employment rate before the earthquake. 
6) Residents of L'Aquila and Perugia had very similar characteristics before the earthquake.

Table 1 shows mean equality tests for several variables using data for the first quarter of 2009. From this Table one can observe that no statistically significant differences for all our control variables were found between residents of the target and control areas in the preearthquake period.

\section{Insert Table 1 about here}

We can denote the second difference by $\left(Y_{\text {Perugia }}^{\text {After }}-Y_{\text {Perugia }}^{\text {Before }}\right)$, so that our DiD estimator is $\delta=($ $\left.Y_{\text {Aquila }}^{\text {After }}-Y_{\text {Aquila }}^{\text {Before }}\right)-\left(Y_{\text {Perugia }}^{\text {After }}-Y_{\text {Perugia }}^{\text {Before }}\right)$.

In practice $\delta$ is estimated using regression analysis. Therefore, in line with the approach employed by Staubli (2011) and Groen and Polivka (2008), we estimate the following regression specification, clustering standard errors at the quarter level to account for withinquarter correlation:

$Y_{i t k}=\alpha+\beta_{1}$ Treat $_{i t k}+\delta$ Treat $_{i t k} *$ Post $)+\lambda_{t}+\gamma_{k}+X_{i t k}^{\prime} \varphi+\varepsilon_{i t k}$

where $Y_{i t k}$ is the labour market outcome for individual $\mathrm{i}$ in quarter $\mathrm{t}$ and year $\mathrm{k}$; Treat is a dummy variable for treatment group ( 1 if the individual resides in L'Aquila, and 0 if the individual resides in Perugia); Post is a dummy that takes the value 1 for observations after the earthquake, and 0 otherwise; $\lambda$ is a quarter fixed effect (the first quarter of 2009 is the omitted quarter); $\gamma$ is a year fixed effect (2009 is the omitted year); $X$ is a vector containing a set of time-varying individual-level covariates (gender, age, aged squared, marital status, presence of at least one child aged less than 6 in the household, education, the interaction of 
gender and marital status and the interaction of gender and presence of at least one child aged less than 6 in the household) and $\varepsilon$ is an error term. The coefficient of interest, $\delta$, identifies the (average) effect of the earthquake on the probability of participating in the labour force or the probability of being employed among residents in the province of L'Aquila in the postearthquake period relative to those outcomes for residents in the province of Perugia. The key identifying assumption is that residents of the target area would have experienced the same labour market outcomes as residents of the control area in the absence of the earthquake, after conditioning on observables.

In order to investigate whether the effect of the earthquake varies over time, we loosen up our regression model by replacing Post with a series of dummies for each quarter. Hence we have:

$Y_{i t k}=\alpha+\beta_{1}$ Treat $_{i t k}+\delta_{1}\left(\right.$ Treat $\left._{i t k} * Q_{2-2009}\right)+\delta_{2}\left(\right.$ Treat $\left._{i t k} * Q_{3-2009}\right)+\delta_{3}\left(\right.$ Treat $\left._{i t k} * Q_{4-2009}\right)+$ $+\delta_{4}\left(\right.$ Treat $\left._{i t k} * Q_{1-2010}\right)+\delta_{5}\left(\right.$ Treat $\left._{i t k} * Q_{2-2010}\right)+\lambda_{t}+\gamma_{k}+X_{i t k}^{\prime} \varphi+\varepsilon_{i t k}$

where $Q_{2-2009}$ is a dummy that takes the value 1 for second-quarter observations in 2009, and 0 otherwise; $Q_{3-2009}$ is a dummy that takes the value 1 for third-quarter observations in 2009, and 0 otherwise; $Q_{4-2009}$ is a dummy that takes the value 1 for fourth-quarter observations in 2009, and 0 otherwise; $Q_{1-2010}$ is a dummy that takes the value 1 for first-quarter observations in 2010, and 0 otherwise; and $Q_{2-2010}$ is a dummy that takes the value 1 for second-quarter observations in 2010, and 0 otherwise.

We estimate Equations (1) and (2) using a linear model, irrespective of the fact that both our outcome measures are binary. As noted by Falck et al. (2010), not only is the linear probability framework more robust to mis-specifications, but it also allows us to estimate the 
parameter of interest directly. Whereas in linear models the interpretation of the coefficient of the interaction between two variables is straightforward, this does not hold in non-linear models (Ai and Norton, 2003). Furthermore, as pointed out by Angrist (2001), the problem of causal inference does not significantly differ between limited dependent variables and continuous outcomes. This means that if there are no covariates or the covariates are sparse and discrete, then linear models can be used to estimate models with limited dependent variables as well as models with other types of dependent variables.

Our analysis is accompanied by two caveats. The first concern is that not all the municipalities of the province of L'Aquila were affected by the earthquake. However, in our dataset, given that information is only available at provincial level and not at municipality level, we are forced to assume that our "treatment group" is all individuals residing in the province of L'Aquila. Though this is not ideal, the following arguments suggest that it is a reasonable approximation.

In the aftermath of the natural disaster, the Italian Department of Civil Protection made a list of those municipalities which were severely affected by the earthquake - defined as a magnitude 6 or greater on the MCS scale. This list, which initially included 37 municipalities of the province of L'Aquila (including the municipality of L'Aquila), has grown over time and currently comprises 46 of them. In 2008, the year before the earthquake, the proportion of individuals residing in these municipalities accounted for approximately $51 \%$ of the total population of the province of L'Aquila. The Italian Department of Civil Protection also came up with a second list of municipalities significantly affected by the earthquake, though the registered magnitude was lower than 6 on the MCS scale. This list comprises 12 municipalities of the province of L'Aquila, whose residents in 2008 accounted for more than $24 \%$ of the total population of the province of L'Aquila. 
Our second concern is that few municipalities of the province of Perugia were hit by an earthquake in 1997. However, such a natural disaster, whose intensity was lower relative to the L'Aquila earthquake, is unlikely to have had any long-lasting effects on the Perugia's economy. To start with, only about $14 \%$ of its residents were affected by this earthquake. Additionally, the data given by the Osservatorio sulla ricostruzione (see http://osservatorioricostruzione.regione.umbria.it) provide support for the proposition that the economy was able to recover just a few years after the earthquake.

\section{Empirical Results}

Table 2 reports DiD estimates of the effect of the L'Aquila earthquake on the probability of being in the labour force. Column (1), which presents estimates from a specification that does not include control variables, suggests that the L'Aquila earthquake is associated with a 1.2 percentage point drop in the probability of participating in the labour force, though our DiD coefficient is not statistically significant at the usual confidence levels. However, this basic specification does not account for the possibility that characteristics of residents of L'Aquila and Perugia vary over time, and that these characteristics can be correlated with labour force participation. Therefore, in Column (2) we control for a number of individual-level demographic attributes. These additional variables considerably improve the fit of the model and show a plausible pattern of results. The likelihood of being in the labour force is greater among males, older and higher-educated individuals. Not surprisingly, the effect of marital status differs by gender- whilst being married increases labour force participation among males, the opposite occurs for females. Moving to the variable of primary interest in this study, one may note that the DiD coefficient still has a negative sign and is now marginally statistically significant. Next, in an attempt to investigate whether the effect of the earthquake on labour force participation varied over time, we loosen up our regression model by replacing our post-earthquake variable with five dummies for the second, third and fourth 
quarters of 2009 and for the first and second quarters of 2010. As shown in Column (3), only the estimated coefficients on the interactions between our treatment group indicator and the 2009 quarter dummies are found to be statistically significant. These estimates therefore suggest that the negative effect exerted by the L'Aquila earthquake on labour force participation persisted only for 3 quarters after the event. In line with expectations, the size of this effect appears to be larger in the quarter immediately after the earthquake (i.e. second quarter of 2009) than in the third and fourth quarters of 2009.

\section{Insert Table 2 about here}

Table 3 reports DiD estimates of the effect of the L'Aquila earthquake on the probability of being employed. Estimates from the basic specification, which are reported in Column (1), indicate that our DiD coefficient has a positive sign and is marginally statistically significant. Estimates depicted in Column (2) show that, once we control for individual-level variables, the effect of the L'Aquila earthquake on the probability of being employed is still positive but is no longer statistically significant at the usual confidence levels. It can however be observed that the results on individual demographic attributes are in line with our expectations. Therefore, being male, older and more educated increase the likelihood of having a job. As with labour force participation, the impact of marital status on the probability of being employed is again found to vary by gender. Finally, the estimates reported in Column (3) indicate that the effect of the L'Aquila earthquake on employment likelihood changed over time. While the employment likelihood fell in the second quarter of 2009, it increased in the next 4 quarters. This result is consistent with those of several studies (see, for instance, Ewing et al., 2003 and 2009) showing that the negative effects of natural disasters on labour market outcomes are short-lived and are followed by a recovery that can even surpass pre-disaster outcomes. 
Although in this paper we are unable to identify the reasons behind this employment recovery, it is likely that such a process will have been driven by the considerable growth experienced by the construction industry. Specifically, a programme was implemented to provide temporary housing to residents of L'Aquila displaced by the earthquake. This was the C.A.S.E. project, which involved the construction of 185 seismically isolated and environmentally sustainable buildings. 4,600 homes were built and the overall cost of the project, which started on June $8^{\text {th }} 2009$, was 800 million euro (http://www.protezionecivile.gov.it/resources/cms/documents/Bruxelles_progetto_CASE_en. pdf). Expansion of the construction industry may act as a catalyst for employment growth since, as outlined by Kircheberger (2011), it is associated with significant indirect employment effects. Its development is accompanied by an increase in the demand for intermediate goods that are produced both in the service and manufacturing sectors. It is therefore possible that the overall employment gain generated by the reconstruction process has more than compensated for the employment loss caused by reduced demand for tourism and students services. Not surprisingly, following the earthquake, less tourists visited the Abruzzi in 2009 (Ecosfera, 2011). Moreover, according to data provided by the Ministry of Education, Universities and Research (MIUR), the number of students enrolled at the University of L'Aquila dropped by about 4,000 in the academic year after the earthquake. The important role played by construction-related businesses in helping the economy to recover in the aftermath of natural disasters has also been highlighted by Kroll et al. (1991) and Webb et al. (2000).

On the other hand, our results suggest that the earthquake caused a reduction in the probability of labour force participation for a period of 9 months after the event. Although it is unclear through which channels the earthquake did depress labour force participation, two 
explanations can be advanced. First, real or perceived poor local economic conditions triggered by the earthquake could have deterred individuals from joining the labour force. This effect is known in the literature as the discouraged-worker effect (see, for instance, Benati, 2001). Discouraged workers are those who do not look for a job given the low employment prospects, but they would have searched for it if economic conditions were more favourable. Second, following the earthquake, the large inflows of non-labour income from insurance and public assistance ${ }^{2}$ could have discouraged many individuals from searching for a job. For instance, according to the Legislative Decree "Abruzzo", evacuees are entitled to various benefits, including up to 500 euro per household per month.

The aggregate results reported in Tables 2 and 3 may mask differential experiences for relevant subgroups of the population. To address this issue, in Tables 4 and 5 we estimate Equation (2) separately by level of education and gender, respectively. The estimates reported in Table 4 indicate that the post-earthquake reconstruction offered employment opportunities for people with little education (primary education or less) or with a secondary education. This is consistent with the fact that, as stated above, in the aftermath of natural disasters local economies tend to experience a significant increase in construction-related businesses. On the other hand, our estimates suggest that the earthquake exerted a negative effect on the probability of being in employment among individuals with a tertiary education. This implies that reconstruction efforts are likely to demand less skilled labour. Our results are consistent with those of Rodríguez-Oreggia (2013) who analyses the effects of hurricanes on labour market outcomes in 32 Mexican metropolitan areas between 2000 and 2011. He concludes

\footnotetext{
${ }^{2}$ The role of insurance is likely to be less relevant than that of public assistance in the process of reconstruction following natural disasters. Due to anticipated governmental assistance, individuals tend to underinsure or do not insure at all. This phenomenon is known in the literature as "charity hazard" (Schwarze and Wagner, 2004).
} 
that low-educated workers are more likely to benefit from the post-reconstruction process than highly educated ones.

There is also evidence that the effect of the earthquake on labour force participation varied according to individuals' level of education. The probability of being in the labour force among people with primary education or less increased throughout the post-earthquake period. By contrast, labour market attachment among individuals with either a secondary or a tertiary education consistently decreased in the same period.

In Table 5, we find that in the short-term the earthquake affected the probability of being in employment among men. Men experienced a statistically significant decline in their employment likelihood in the second quarter of 2009, whereas the opposite holds for the third and fourth quarters of 2009. On the other hand, the earthquake is not found to have any statistically significant effect on the probability of having a job among women during the same period. However, following this natural disaster, the first and second quarters of 2010 are both characterised by an increase in the employment likelihood among women.

\section{Insert Tables 4 and 5 about here}

\section{Concluding Remarks}

In this article, we use Labour Force Survey individual-level data to examine the effects of the L'Aquila earthquake on labour market outcomes for a period of 15 months after its occurrence. Our empirical strategy relies on a difference-in-differences method that compares residents of L'Aquila with residents of a control area before and after the earthquake. Our estimates indicate that the earthquake led to a modest, but statistically significant, reduction in the probability of participating in the labour force for a period of 9 months after the event. While the overall impact on the employment likelihood is not significant, this result masks 
significant opposing effects over time. The employment likelihood fell in the quarter immediately after the earthquake, while it increased in the next 4 quarters.

Our analysis highlights that there are important differential effects by gender. While the earthquake led to an overall decline in the employment likelihood in the second quarter of 2009, this effect is confined mostly to men. Similarly, the overall increase in the employment likelihood observed during the third and fourth quarters of 2009 is also primarily confined to men. Our results show also evidence of significant heterogeneous effects across educational levels. When the sample is cut by education group, two opposite and significant effects for individuals with low and high education are found. While the earthquake is related to higher labour force participation and higher employment opportunities for individuals with primary education or less, it is associated with worsening labour market conditions for those with a tertiary education.

The findings from this study suggest that natural disasters may have important policy implications. Given that more educated individuals are likely to experience negative labour market outcomes following earthquakes, in the post-recovery period policymakers should consider the possibility of adopting measures aimed at increasing their labour force participation and improving their employment prospects. 


\section{References}

Abruzzo24ore.tv, 2012, "Il prima e il dopo sisma dell' economia aquilana in un dossier della Confcommercio", 13 April 2012, http://www.abruzzo24ore.tv/news/Il-prima-e-il-doposisma-dell-economia-aquilana-in-un-dossier-della-Confcommercio/79110.htm

Ai C, Norton E, 2003, "Interaction terms in logit and probit models" Economics Letters 80(1) $123-129$

Ajassa G, 2009, "In declino già prima del sisma l'università motore della città", La $\begin{array}{llll}\text { Repubblica, } & 20 & \text { April } & 2009\end{array}$ http://ricerca.repubblica.it/repubblica/archivio/repubblica/2009/04/20/in-declino-gia-primadel-sisma-universita.html

Albala-Bertrand J M, 1993, Political economy of large natural disasters (Clarendon Press Oxford, UK)

Angrist J D, 2001, "Estimation of limited-dependent variable models with binary endogenous regressors: simple strategies for empirical practice" Journal of Business Economics and Statistics 19(1) 2-16

Belasen A R, Polachek S W, 2008, "How hurricanes affect wages and employment in local labor markets?" American Economic Review, 98(2) 49-53

Benati L, 2001, "Some empirical evidence on the 'discouraged worker' effect" Economics Letters 70(3) 387-395

Bryson A, Dorsett R, Purdon S, 2002, "The use of propensity score matching in the evaluation of active labour market policies", WP 4, UK Department for Work and Pensions 
Cavallaro M, 2011, "L'Aquila: la situazione economica prima del terremoto", 8 April 2011, http://www.youtrend.it/laquila-la-situazione-economica-prima-del-terremoto/

Cavallo E, Galiani S, Noy I, Pantano J, 2010, "Catastrophic natural disasters and economic growth”, IDB-WP-183, Inter-American Development Bank, Washington, DC

Cavallo E, Noy I, 2009, “The economics of natural disasters- A survey”, WP 200919, University of Hawaii at Manoa, Department of Economics

Cheong S M, 2011, “The role of government in disaster management: the case of the Hebei Spirit oil spill compensation" Environment and Planning C: Government and Policy 29(6) 1073-1086

Coffman M, Noy I, 2012, "Hurricane Iniki: measuring the long-term economic impact of a natural disaster using synthetic control" Environment and Development Economics 17(2) $187-205$

Commissariato delegato per la ricostruzione in Abruzzo, 2011, "Prime considerazioni sugli scenari di sviluppo e le strategie di intervento da mettere in campo per il territorio dell'Aquila", $\quad$ http://www.commissarioperlaricostruzione.it/Informare/Normative-eDocumenti/Atti-e-documenti-della-Struttura-Tecnica-di-Missione-STM/Idee-e-strumenti-perla-ricostruzione-pesante/Prime-considerazioni-sulle-strategie-di-sviluppo-e-gli-scenari-diintervento-da-mettere-in-campo-per-il-territorio-dell-Aquila

Cuaresma J C, Hlouskova J, Obersteiner M, 2008, "Natural disasters as creative destruction? Evidence from developing countries" Economic Inquiry 46(2) 214-226

Dorsett R, 2005, "Unemployed couples: the labour market effects of making both partners search for work" Journal of the Royal Statistical Society A 168(2) 365-385 
Ecosfera, 2011, “Approfondimento tematico sulle azioni a sostegno della rivitalizzazione $\begin{array}{llll}\text { economica } & \text { e } & \text { sociale } & \text { del }\end{array}$ http://www.dps.tesoro.it/documentazione/snv/piani_valutazione/abruzzo/Approfondimento_ Asse_VI_def\%20Abruzzo.pdf

Ewing B T, Kruse J B, Thompson M A, 2009, “Twister! Employment Responses to the 3 May 1999 Oklahoma City Tornado" Applied Economics 41(4) 691-702

Ewing B T, Kruse J B, Thompson M A, 2005, "Empirical examination of the Corpus Christi unemployment and hurricane Bret" Natural Hazards Review 6(4) 191-196

Ewing B T, Kruse J B, 2002, "The impact of project impact on the Wilmington, North Carolina, labour market" Public Finance Review 30(4) 296-309

Ewing B T, Kruse J B, Thompson M A, 2003, "A comparison of employment growth and stability before and after the Fort Worth Tornado" Environmental Hazards 5(3-4) 83-91

Falck O, Heblich S, Kipar S, 2010, "Industrial innovation: direct evidence from a clusteroriented policy" Regional Science and Urban Economics 40(6) 574-582

Görlitz K, 2010, “The effect of subsidizing continuous training investments- evidence from German establishment data" Labour Economics 17(5) 789-798

Groen J A, Polivka A E, 2008, “The effect of Hurricane Katrina on the labour market outcomes of evacuees" American Economic Review 98(2) 43-48

Ilzetzki E, Végh C, 2008, "Procyclical fiscal policy in developing countries: truth or fiction? ", WP 14191, National Bureau of Economic Research, Cambridge, MA

Jones E, 1981, The European miracle: environments, economies and geopolitics in the history of Europe and Asia (Cambridge University Press, Cambridge) 
Karoly L A, Zissimopoulos J, 2010, "The workforce and economic recovery. Effects of hurricane Katrina”, Research Brief 9531, RAND Gulf States Policy Institute

Kim C K, 2010, "The effects of natural disasters on long-run economic growth" The Michigan Journal of Business 41 15-49

Kircheberger M, 2011, "Natural disasters and labour market", paper presented at the spring meeting of young economists, University of Groningen, 14-16 April

Korkeamäki O, Uusitalo R, 2009, "Employment and wage effects of a payroll-tax cut evidence from a regional experiment" International Tax and Public Finance 16(6) 753-772

Kroll C A, Landis J D, Shen Q, Stryker S, 1991, "Economic impacts of the Loma Prieta earthquake: A focus on small business", WP 91-187, UC Transportation Center and the Center for real estate and Urban Economics, University of California at Berkeley

Loayza N, Olaberría E, Rigolini J, Christiaensen L, 2009, "Natural disasters and growth. Going beyond the averages", WP 4980, World Bank

Marchand J, 2012, "Local labour market impacts of energy boom-bust-boom in Western Canada" Journal of Urban Economics 71(1) 165-174

Martin S F, 2012, "Environmental change and migration: legal and political frameworks" Environment and Planning C: Government and Policy 30(6) 1045-1060

Masi A, 2009, "Prime riflessioni sull'esperienza del terremoto in Abruzzo", Consiglio nazionale degli ingegneri, $\quad$ http://www.tuttoingegnere.it/ITA/In-evidenz/Ilterremo/TERREMOTO-Opuscolo---visualizzazione.pdf

Mauro G, 2009 “L’evoluzione dell'economia abruzzese: alcuni elementi critici” in Rapporto sull'Economia Abruzzese: Rapporto sull'Economia Abruzzese 2008, CRESA Centro 
Regionale di Studi e Ricerche Economico Sociali, http://www.cresa.it/pubblicazioni/rapporti/2008/R_2k8.pdf

McComb R, Moh Y-K, Schiller A R, 2011, "Measuring long-run economic effects of natural hazard" Natural Hazards 58(1) 559-566

Noy I, 2012, "The enduring economic aftermath of natural catastrophes", Vox, http://www.voxeu.org/article/economic-consequences-natural-catastrophes

Raschky P A, 2008, "Institutions and the losses from natural disasters" Natural Hazards and Earth System Sciences 8(4) 627-634

Rodríguez-Oreggia E, 2013, "Hurricanes and labor market outcomes: Evidence for Mexico" Global Environment Change 23(1) 251-359

Schwarze R, Wagner G G, 2004, "In the aftermath of Dresden: new directions in German flood insurance" The Geneva Papers on Risk and Insurance 29(2) 164-168

Skidmore M, Toya H, 2002, "Do natural disasters promote long-run growth?" Economic Inquiry 40(4) 664-687

Staubli S, 2011, "The impact of stricter criteria for disability insurance on labour force participation” Journal of Public Economics 95(9-10) 1223-123

Toya H, Skidmore M, 2007, "Economic development and the impact of natural disasters" Economics Letters 94(1) 20-25

Webb G R, Tierney K J, Dahlhamer J M, 2000, “Business and disasters: empirical patterns and unanswered questions" Natural Hazard Review 1(2) 83-90

Xu G, 2011, "Long-run consequences of natural disasters: evidence from Tangshan", DIW Berlin No. 1117, German Institute for Economic Research 


\section{FIGURE 1}

Central Italy -provinces of Perugia and L'Aquila

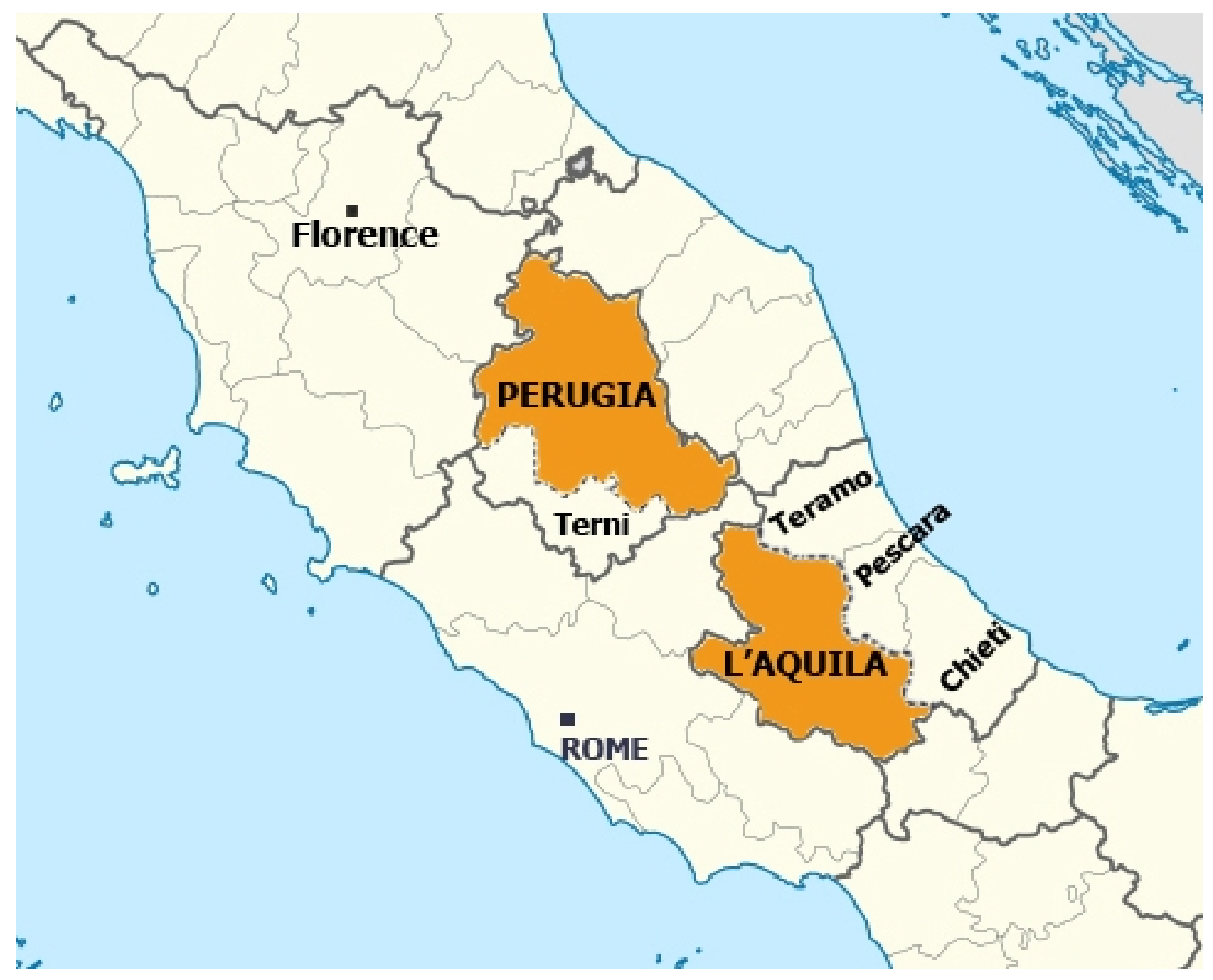




\section{FIGURE 2}

Trends in labour market outcomes in the target and control areas before the L'Aquila earthquake

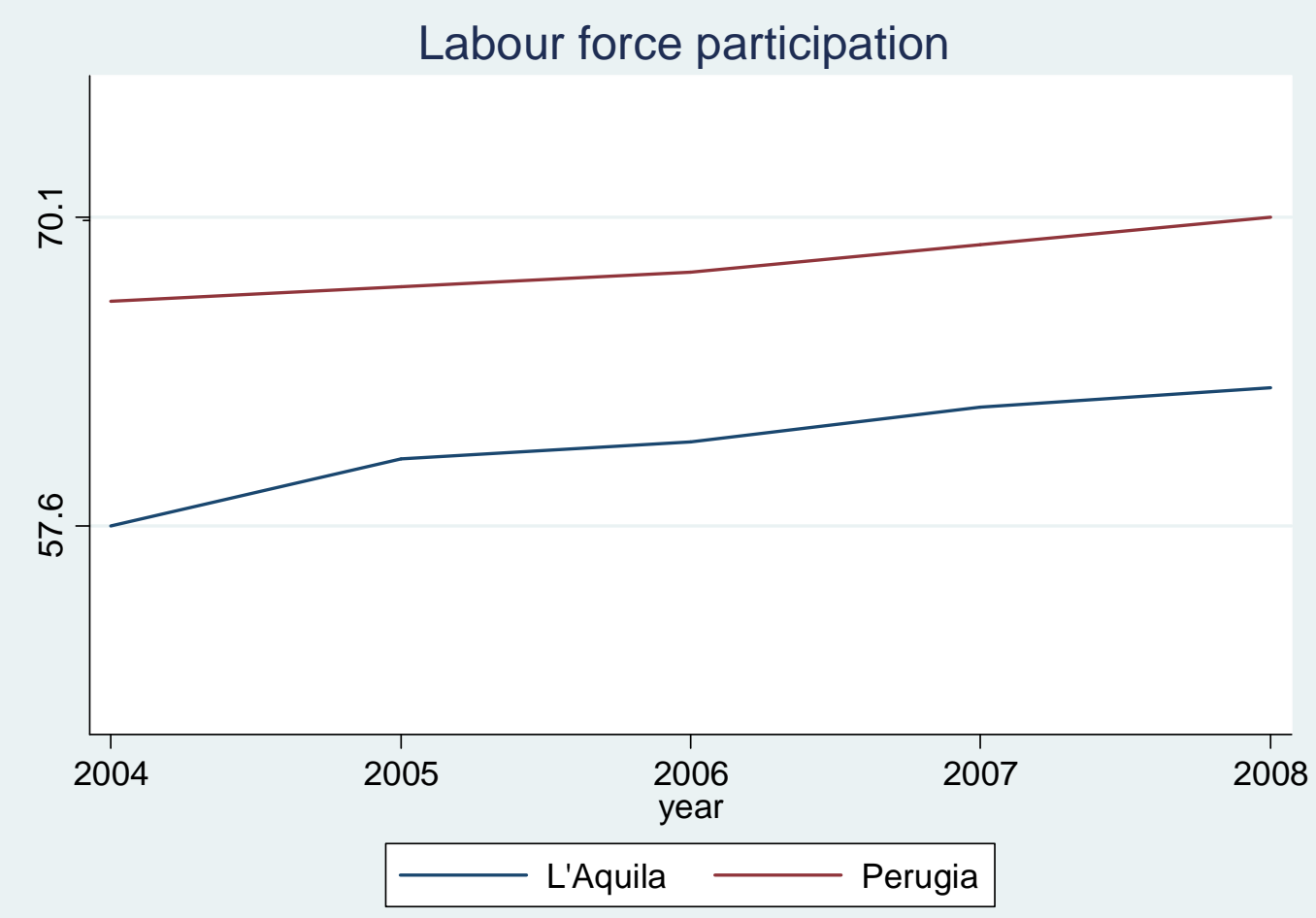

Employment rate

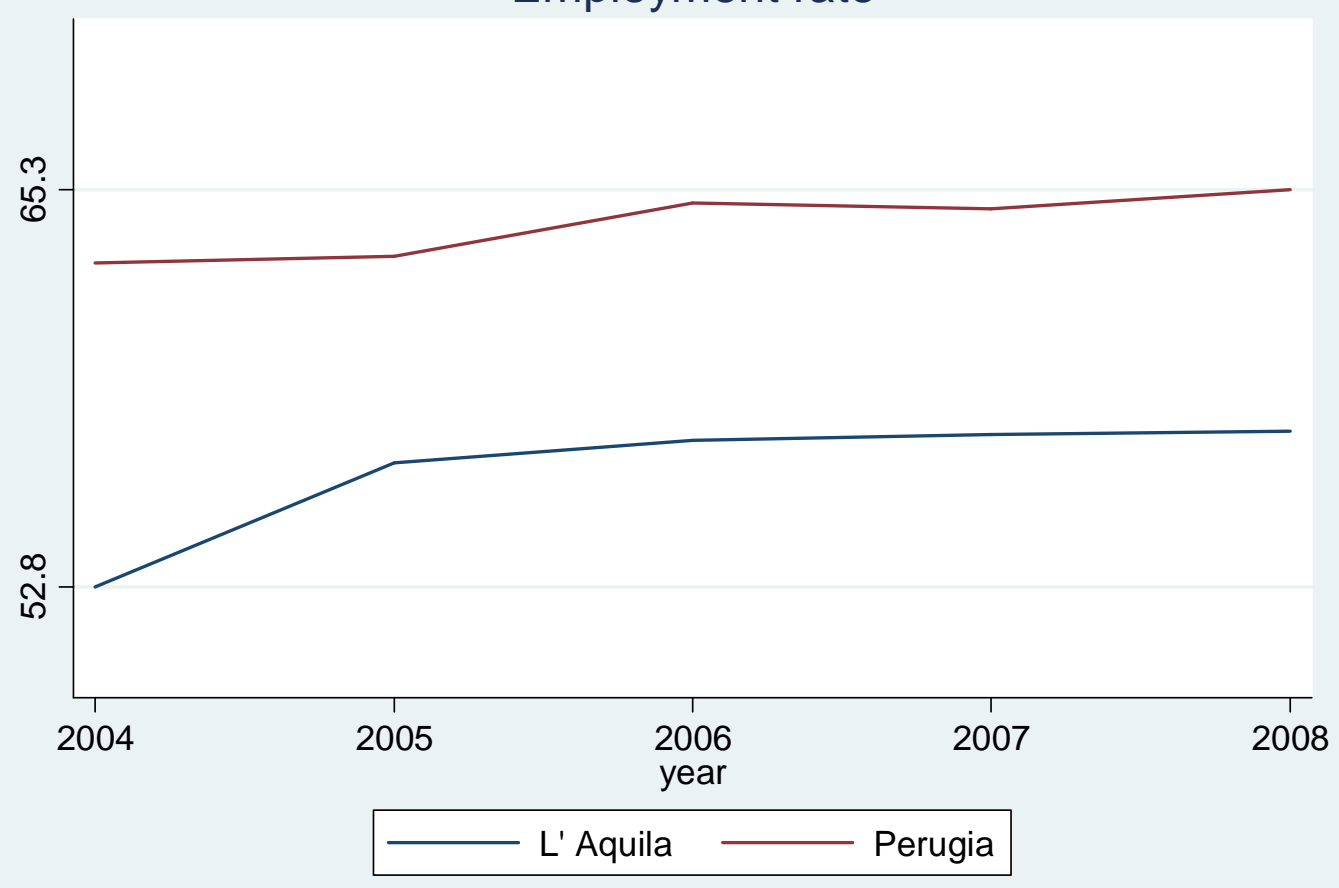

In both diagrams the $y$-axis starts at 50 
Table 1

Mean equality tests

\begin{tabular}{lccc}
\hline \multicolumn{1}{c}{ Individual characteristic } & $\begin{array}{c}\text { Treatment group } \\
\text { (Residents of L'Aquila) }\end{array}$ & $\begin{array}{c}\text { Control group } \\
\text { (Residents of Perugia) }\end{array}$ & Diff. \\
\hline Female & 0.495 & 0.502 & -0.007 \\
Age (years) & $(0.500)$ & $(0.500)$ & $(0.027)$ \\
& 40.497 & 40.472 & 0.025 \\
Married & $(13.895)$ & $(13.432)$ & $(0.734)$ \\
& 0.539 & 0.570 & -0.031 \\
Presence of at least one child & $(0.499)$ & $(0.495)$ & $(0.027)$ \\
aged less than 6 in the & 0.113 & 0.133 & -0.20 \\
household & $(0.317)$ & $(0.340)$ & $(0.020)$ \\
& & & \\
Education & & & \\
Primary education or less & 0.072 & 0.083 & -0.011 \\
& $(0.258)$ & $(0.276)$ & $(0.013)$ \\
Secondary education & 0.782 & 0.768 & 0.014 \\
& $(0.413)$ & $(0.422)$ & $(0.023)$ \\
Tertiary education & 0.146 & 0.149 & -0.003 \\
Observations & $(0.354)$ & $(0.357)$ & $(0.020)$ \\
\hline
\end{tabular}

Notes:

Data refer to the first quarter of 2009 (i.e. pre-earthquake period)

Standard deviations are reported in brackets

LFS sampling weights are used 


\section{Table 2}

The effect of the L'Aquila earthquake on the probability of labour force participation

\begin{tabular}{|c|c|c|c|}
\hline Dependent variable & (1) & (2) & (3) \\
\hline Constant & $\begin{array}{c}0.686 * * * \\
(0.001)\end{array}$ & $\begin{array}{c}-1.211 * * * \\
(0.036)\end{array}$ & $\begin{array}{c}-1.207 * * * \\
(0.032)\end{array}$ \\
\hline Treat & $\begin{array}{c}-0.065^{* * *} * \\
(0.001)\end{array}$ & $\begin{array}{c}-0.053^{* * *} * \\
(0.001)\end{array}$ & $\begin{array}{c}-0.056^{* * *} * \\
(0.003)\end{array}$ \\
\hline Treat $*$ Post & $\begin{array}{l}-0.012 \\
(0.010)\end{array}$ & $\begin{array}{c}-0.018^{*} \\
(0.008)\end{array}$ & \\
\hline Treat $^{*} Q_{2-2009}$ & & & $\begin{array}{c}-0.040 * * * \\
(0.004)\end{array}$ \\
\hline Treat $* Q_{3-2009}$ & & & $\begin{array}{c}-0.016^{* *} \\
(0.004)\end{array}$ \\
\hline Treat $* Q_{4-2009}$ & & & $\begin{array}{c}-0.025 * * * \\
(0.004)\end{array}$ \\
\hline Treat $* Q_{1-2010}$ & & & $\begin{array}{c}0.002 \\
(0.004)\end{array}$ \\
\hline Treat $^{*} Q_{2-2010}$ & & & $\begin{array}{c}0.010 \\
(0.006)\end{array}$ \\
\hline Female & & $\begin{array}{c}-0.099 * * * \\
(0.005)\end{array}$ & $\begin{array}{c}-0.099 * * * \\
(0.005)\end{array}$ \\
\hline Age (years) & & $\begin{array}{c}0.113 * * * \\
(0.002)\end{array}$ & $\begin{array}{c}0.113 * * * \\
(0.002)\end{array}$ \\
\hline Age squared & & $\begin{array}{c}-0.001 * * * \\
(0.000)\end{array}$ & $\begin{array}{c}-0.001 * * * \\
(0.000)\end{array}$ \\
\hline Married & & $\begin{array}{c}0.041 * * \\
(0.010)\end{array}$ & $\begin{array}{c}0.041 * * \\
(0.010)\end{array}$ \\
\hline $\begin{array}{l}\text { Presence of at least one } \\
\text { child aged less than } 6 \text { in } \\
\text { the household }\end{array}$ & & $\begin{array}{l}-0.003 \\
(0.014)\end{array}$ & $\begin{array}{l}-0.002 \\
(0.014)\end{array}$ \\
\hline Female*Married & & $\begin{array}{c}-0.131^{* * * *} \\
(0.009)\end{array}$ & $\begin{array}{c}-0.131 * * * \\
(0.009)\end{array}$ \\
\hline $\begin{array}{l}\text { Female* presence of at } \\
\text { least one child aged less } \\
\text { than } 6 \text { in the household }\end{array}$ & & $\begin{array}{c}-0.058^{*} \\
(0.026)\end{array}$ & $\begin{array}{c}-0.059^{*} \\
(0.026)\end{array}$ \\
\hline \multicolumn{4}{|c|}{ Education- Reference category is "Tertiary education" } \\
\hline Primary education or less & & $\begin{array}{c}-0.262 * * * \\
(0.014)\end{array}$ & $\begin{array}{c}-0.261 * * * \\
(0.014)\end{array}$ \\
\hline Secondary education & & $\begin{array}{c}-0.077 * * * \\
(0.013)\end{array}$ & $\begin{array}{c}-0.077 * * * \\
(0.013)\end{array}$ \\
\hline R-squared & 0.006 & 0.358 & 0.359 \\
\hline Observations & 13,124 & 13,124 & 13,124 \\
\hline
\end{tabular}

Notes:

Regressions are estimated as linear models and weighted using LFS sampling weights. Robust standards errors, which are clustered by quarter level, are reported in brackets. All regressions include quarter and year fixed effects.

*** indicates statistical significance at $1 \%, * *$ indicates statistical significance at $5 \%$; $*$ indicates statistical significance at $10 \%$ 
Table 3

The effect of the L'Aquila earthquake on the employment likelihood

\begin{tabular}{|c|c|c|c|}
\hline Dependent variable & (1) & (2) & (3) \\
\hline Constant & $\begin{array}{c}0.641 * * * \\
(0.002)\end{array}$ & $\begin{array}{c}-1.183 * * * \\
(0.054)\end{array}$ & $\begin{array}{c}-1.179 * * * \\
(0.051)\end{array}$ \\
\hline Treat & $\begin{array}{c}-0.105^{* * *} * \\
(0.002)\end{array}$ & $\begin{array}{c}-0.094 * * * \\
(0.002)\end{array}$ & $\begin{array}{c}-0.098 * * * \\
(0.003)\end{array}$ \\
\hline Treat * Post & $\begin{array}{l}0.025^{*} \\
(0.012)\end{array}$ & $\begin{array}{c}0.019 \\
(0.010)\end{array}$ & \\
\hline Treat $* Q_{2-2009}$ & & & $\begin{array}{c}-0.016 * * * \\
(0.003)\end{array}$ \\
\hline Treat $* Q_{3-2009}$ & & & $\begin{array}{c}0.028 * * * \\
(0.004)\end{array}$ \\
\hline Treat $* Q_{4-2009}$ & & & $\begin{array}{c}0.013 * * * \\
(0.003)\end{array}$ \\
\hline Treat $* Q_{1-2010}$ & & & $\begin{array}{c}0.049 * * * \\
(0.003)\end{array}$ \\
\hline Treat $^{*} Q_{2-2010}$ & & & $\begin{array}{c}0.047 * * * \\
(0.004)\end{array}$ \\
\hline Female & & $\begin{array}{c}-0.105^{* * * *} \\
(0.006)\end{array}$ & $\begin{array}{c}-0.105 * * * \\
(0.006)\end{array}$ \\
\hline Age (years) & & $\begin{array}{c}0.107 * * * \\
(0.003)\end{array}$ & $\begin{array}{c}0.107 * * * \\
(0.003)\end{array}$ \\
\hline Age squared & & $\begin{array}{c}-0.001 * * * \\
(0.000)\end{array}$ & $\begin{array}{c}-0.001 * * * \\
(0.000)\end{array}$ \\
\hline Married & & $\begin{array}{c}0.066^{* * * *} \\
(0.013)\end{array}$ & $\begin{array}{c}0.067 * * * \\
(0.013)\end{array}$ \\
\hline $\begin{array}{l}\text { Presence of at least one } \\
\text { child aged less than } 6 \text { in } \\
\text { the household }\end{array}$ & & $\begin{array}{c}0.010 \\
(0.009)\end{array}$ & $\begin{array}{c}0.011 \\
(0.009)\end{array}$ \\
\hline Female*Married & & $\begin{array}{c}-0.138 * * * \\
(0.013)\end{array}$ & $\begin{array}{c}-0.138 * * * \\
(0.013)\end{array}$ \\
\hline $\begin{array}{l}\text { Female* presence of at } \\
\text { least one child aged less } \\
\text { than } 6 \text { in the household }\end{array}$ & & $\begin{array}{c}-0.078 * * \\
(0.023)\end{array}$ & $\begin{array}{c}-0.079 * * \\
(0.023)\end{array}$ \\
\hline Education- Reference cate & “Tertiary ec & & \\
\hline Primary education or less & & $\begin{array}{c}-0.291 * * * \\
(0.017)\end{array}$ & $\begin{array}{c}-0.291 * * * \\
(0.016)\end{array}$ \\
\hline Secondary education & & $\begin{array}{c}-0.082 * * * * \\
(0.014)\end{array}$ & $\begin{array}{c}-0.082 * * * \\
(0.014)\end{array}$ \\
\hline R-squared & 0.007 & 0.323 & 0.324 \\
\hline Observations & 13,124 & 13,124 & 13,124 \\
\hline
\end{tabular}

\section{Notes:}

Regressions are estimated as linear models and weighted using LFS sampling weights. Robust standards errors, which are clustered by quarter level, are reported in brackets. All regressions include quarter and year fixed effects.

*** indicates statistical significance at $1 \%, * *$ indicates statistical significance at $5 \%$; indicates statistical significance at $10 \%$ 


\section{Table 4}

Effects of the L'Aquila earthquake on labour market outcomes by level of education

\begin{tabular}{|c|c|c|c|c|c|c|}
\hline & \multicolumn{3}{|c|}{ Probability of being in the labour force } & \multicolumn{3}{|c|}{ Employment likelihood } \\
\hline & $\begin{array}{c}\text { (1) } \\
\text { Individuals } \\
\text { with primary } \\
\text { education or } \\
\text { less }\end{array}$ & $\begin{array}{c}(2) \\
\text { Individuals } \\
\text { with a } \\
\text { secondary } \\
\text { education }\end{array}$ & $\begin{array}{c}(3) \\
\text { Individuals } \\
\text { with a } \\
\text { tertiary } \\
\text { education }\end{array}$ & $\begin{array}{c}(4) \\
\text { Individuals } \\
\text { with } \\
\text { primary } \\
\text { education } \\
\text { or less } \\
\end{array}$ & $\begin{array}{c}(5) \\
\text { Individuals } \\
\text { with a } \\
\text { secondary } \\
\text { education }\end{array}$ & $\begin{array}{c}(6) \\
\text { Individuals } \\
\text { with a } \\
\text { tertiary } \\
\text { education }\end{array}$ \\
\hline Treat $* Q_{2-2009}$ & $\begin{array}{c}0.048 * * \\
(0.013)\end{array}$ & $\begin{array}{c}-0.056 * * * \\
(0.003)\end{array}$ & $\begin{array}{l}-0.022 \\
(0.020)\end{array}$ & $\begin{array}{c}0.020 \\
(0.011)\end{array}$ & $\begin{array}{c}-0.024 * * \\
(0.008)\end{array}$ & $\begin{array}{l}-0.013 \\
(0.010)\end{array}$ \\
\hline Treat $* Q_{3-2009}$ & $\begin{array}{c}0.044 * * * \\
(0.009)\end{array}$ & $\begin{array}{c}-0.012 * * * \\
(0.001)\end{array}$ & $\begin{array}{c}-0.116 * * * \\
(0.015)\end{array}$ & $\begin{array}{l}0.050 * * * \\
(0.010)\end{array}$ & $\begin{array}{c}0.037 * * * \\
(0.003)\end{array}$ & $\begin{array}{c}-0.106 * * * \\
(0.015)\end{array}$ \\
\hline Treat $* Q_{4-2009}$ & $\begin{array}{c}0.040 * * * \\
(0.007)\end{array}$ & $\begin{array}{c}-0.019 * * * \\
(0.002)\end{array}$ & $\begin{array}{c}-0.101 * * * \\
(0.013)\end{array}$ & $\begin{array}{c}0.050 * * \\
(0.013)\end{array}$ & $\begin{array}{c}0.028 * * * \\
(0.004)\end{array}$ & $\begin{array}{c}-0.117 * * * \\
(0.010)\end{array}$ \\
\hline Treat $* Q_{1-2010}$ & $\begin{array}{c}0.016 * * \\
(0.006)\end{array}$ & $\begin{array}{l}-0.002 * * * \\
(0.0003)\end{array}$ & $\begin{array}{c}-0.028 * * * \\
(0.002)\end{array}$ & $\begin{array}{c}0.008 \\
(0.009)\end{array}$ & $\begin{array}{l}0.045^{* * *} * \\
(0.0002)\end{array}$ & $\begin{array}{l}-0.006^{*} \\
(0.003)\end{array}$ \\
\hline Treat $* Q_{2-2010}$ & $\begin{array}{c}0.145^{* * *} * \\
(0.014)\end{array}$ & $\begin{array}{l}-0.001 \\
(0.003)\end{array}$ & $\begin{array}{c}-0.072 * * \\
(0.020)\end{array}$ & $\begin{array}{l}0.059 * * * \\
(0.009)\end{array}$ & $\begin{array}{l}0.035 * * * \\
(0.008)\end{array}$ & $\begin{array}{l}-0.021^{*} \\
(0.010)\end{array}$ \\
\hline R-squared & 0.313 & 0.348 & 0.177 & 0.256 & 0.315 & 0.192 \\
\hline Observations & 1,198 & 10,106 & 1,820 & 1,198 & 10,106 & 1,820 \\
\hline
\end{tabular}

Notes:

Regressions are estimated as linear models and weighted using LFS sampling weights. Robust standards errors, which are clustered by quarter level, are reported in brackets.

In addition to quarter and year fixed effects, all regressions include a constant and the following individual-level covariates: gender, residing in L'Aquila, age, age squared, marital status, presence of at least one child aged less than 6 in the household, interaction of gender and marital status and interaction of gender and presence of at least one child aged less than 6 in the household

*** indicates statistical significance at $1 \%, * *$ indicates statistical significance at $5 \%$; $*$ indicates statistical significance at $10 \%$ 


\section{Table 5}

Effects of the L'Aquila earthquake on labour market outcomes by gender

\begin{tabular}{|c|c|c|c|c|}
\hline & \multicolumn{2}{|c|}{$\begin{array}{c}\text { Probability of being in the labour } \\
\text { force }\end{array}$} & \multicolumn{2}{|c|}{ Employment likelihood } \\
\hline & $\begin{array}{c}(1) \\
\text { Males }\end{array}$ & $\begin{array}{c}(2) \\
\text { Females }\end{array}$ & $\begin{array}{c}(3) \\
\text { Males }\end{array}$ & $\begin{array}{c}(4) \\
\text { Females }\end{array}$ \\
\hline Treat $* Q_{2-2009}$ & $\begin{array}{c}-0.045 * * * \\
(0.006)\end{array}$ & $\begin{array}{c}-0.040 * * \\
(0.013)\end{array}$ & $\begin{array}{c}-0.027 * * * \\
(0.006)\end{array}$ & $\begin{array}{l}-0.008 \\
(0.011)\end{array}$ \\
\hline Treat $* Q_{3-2009}$ & $\begin{array}{c}-0.027 * * * \\
(0.004)\end{array}$ & $\begin{array}{l}-0.011 \\
(0.012)\end{array}$ & $\begin{array}{c}0.031 * * * \\
(0.004)\end{array}$ & $\begin{array}{c}0.021 \\
(0.012)\end{array}$ \\
\hline Treat $^{*} Q_{4-2009}$ & $\begin{array}{l}0.010 * \\
(0.004)\end{array}$ & $\begin{array}{c}-0.064 * * * \\
(0.012)\end{array}$ & $\begin{array}{l}0.027 * * * \\
(0.004)\end{array}$ & $\begin{array}{l}-0.005 \\
(0.011)\end{array}$ \\
\hline Treat $* Q_{1-2010}$ & $\begin{array}{l}-0.002 \\
(0.005)\end{array}$ & $\begin{array}{c}0.001 \\
(0.012)\end{array}$ & $\begin{array}{l}0.028 * * * \\
(0.005)\end{array}$ & $\begin{array}{c}0.066 * * * \\
(0.011)\end{array}$ \\
\hline Treat ${ }^{*} Q_{2-2010}$ & $\begin{array}{c}-0.032 * * * \\
(0.007)\end{array}$ & $\begin{array}{l}0.051 * * \\
(0.018)\end{array}$ & $\begin{array}{l}-0.006 \\
(0.007)\end{array}$ & $\begin{array}{c}0.101^{* * * *} \\
(0.016)\end{array}$ \\
\hline R-squared & 0.411 & 0.285 & 0.366 & 0.251 \\
\hline Observations & 6,507 & 6,617 & 6,507 & 6,617 \\
\hline
\end{tabular}

Notes:

Regressions are estimated as linear models and weighted using LFS sampling weights. Robust standards errors, which are clustered by quarter level, are reported in brackets.

In addition to quarter and year fixed effects, all regressions include a constant and the following individual-level covariates: residing in L'Aquila, age, age squared, marital status, education and presence of at least one child aged less than 6 in the household.

*** indicates statistical significance at $1 \%, * *$ indicates statistical significance at $5 \%$; $*$ indicates statistical significance at $10 \%$ 


\section{Appendix}

Average characteristics of residents of L'Aquila before and after the earthquake

\begin{tabular}{lcc}
\hline \multicolumn{1}{c}{$\begin{array}{c}\text { Individual } \\
\text { characteristic }\end{array}$} & $\begin{array}{c}\text { Residents of L'Aquila } \\
\text { before the earthquake }\end{array}$ & $\begin{array}{c}\text { Residents of L'Aquila } \\
\text { after the earthquake }\end{array}$ \\
\hline Female & 0.495 & 0.495 \\
& $(0.500)$ & $(0.500)$ \\
Age (years) & 40.497 & 40.442 \\
& $(13.895)$ & $(13.685)$ \\
Married & 0.539 & 0.565 \\
& $(0.499)$ & $(0.496)$ \\
Presence of at least one & 0.113 & 0.112 \\
child aged less than 6 & $(0.317)$ & $(0.315)$ \\
in the household & & \\
& & \\
Education & & \\
Primary education or & 0.072 & 0.081 \\
less & $(0.258)$ & $(0.274)$ \\
Secondary education & 0.782 & 0.781 \\
& $(0.413)$ & $(0.414)$ \\
Tertiary education & 0.146 & 0.138 \\
& $(0.354)$ & $(0.344)$ \\
Observations & 533 & 2,951 \\
\hline
\end{tabular}

Notes:

Data refer to the first quarter of 2009 (pre-earthquake period) and to the second, third and fourth quarters of 2009 and the first and second quarters of 2010 (post-earthquake period).

Standard deviations are reported in brackets

LFS sampling weights are used 